IJAMSR 3 (5) www.ijamsr.com CrossRef: https://doi.org/10.31426/ijamsr.2020.3.5.3314

International Journal of

Advanced Multidisciplinary Scientific Research (IJAMSR) ISSN:2581-4281

\title{
Differences in Students' Writing Skills through the Application of Group Investigative Learning and Role Play Model
}

\author{
Andri Pitoyo \\ Universitas Nusantara PGRI Kediri, East Java, Indonesia, \\ Email: andripitoyo@unpkediri.ac.id
}

Keywords:

Writing Skills

Group Investigation

Role Play Model

\begin{abstract}
A B S T RA C T
Writing skills, as one aspect of language skills, play a very important and strategic role. This can be observed from every discipline that requires writing. The purpose of this study was to determine differences in students' writing skills through the application of group investigation learning model and role play model. Sampling was done by using a multi-stage area random sampling technique amount to 240 students from 12 elementary schools in Kediri, East Java, Indonesia. The research model used in this study is an experimental model with classes divided into an experimental class and a control class. Data collection uses tests, questionnaires, and documentation. The data analysis technique used independent sample t-test. The results showed there were differences in the average writing skills of students who were taught using the group investigation model with the role play model. The writing skills of students taught using the group investigation model were 126 people with an average value of 80.42 better than the group of students with the role play model amount to 114 people with an average grade of 76.34. Writing skills in terms of content relevance, content organization, cohesive and paragraph coherence, choice of words, and the use of spelling on students with group investigation model have a percentage achievement of $80 \%$ better than students with role play model that have a percentage of only $74 \%$.
\end{abstract}

Citation: Andri Pitoyo (2020). Differences in Students' Writing Skills through the Application of Group Investigative Learning and Role Play Model. International Journal of Advanced Multidisciplinary Scientific Research (IJAMSR) ISSN:2581-4281, 3 (5), May 2020, Pp 32 - 46 
IJAMSR 3 (5) www.ijamsr.com CrossRef: https://doi.org/10.31426/ijamsr.2020.3.5.3314

\section{J A M S R}

\section{International Journal of Advanced Multidisciplinary Scientific Research (IJAMSR) ISSN:2581-4281}

\section{Introduction}

Writing is one of the most organized and effective ways to express meaningful ideas to others. The author can express his ideas systematically, make revisions, and perfect the results of his writings so that the information revealed can be understood well by the readers. The development of writing skills, as well as oral language skills, requires an understanding of how to combine linguistic components (for example: knowledge of vocabulary, grammar, orthography, and type structure) to produce a text. In writing, an author must also make a proper analysis of the topic to be written so that it is actual, interesting and desirable and understood by readers (Malladewi, 2013; Yarmi, 2014).

Learning to write according to the modern approach is learning that not only emphasizes the product, but also the process. In its implementation, students feel direct experience in writing activities. Thus, students and teachers must realize that writing is a process and gradual. Therefore, in learning to write, the teacher should prepare the conditions for students to understand how to learn to write and not just learn to write. The basic concept of this approach provides opportunities for students not to depend entirely on the teacher, but more than that students are also expected to be able to take responsibility for their writing and be able to collaborate with other students. Thus the teacher acts as a facilitator, motivator, and organizer in creating a conducive atmosphere in learning to write (Astuti \& Mustadi, 2014; Lin, Li, Hung, \& Huang, 2014).

Based on preliminary surveys and interviews with a number of elementary school teachers (at the PLPG at Rayon 143 UNP Kediri Phase 2 and 3), it is known that grade $\mathrm{V}$ students in Blabak I Elementary School, Kandat District, Kediri Regency, out of 49 students only $15 \%$ (7 students) were managed to make essays with enough categories. Furthermore, in Krecek I Elementary School, Badas District, Kediri Regency, of 83 students, only 40\% (33 students) succeeded in making essays through cooperative learning model. Facts in Ngadiluwih II Public Elementary School Ngadiluwih Subdistrict, Kediri Regency, of the 94 students there were $30 \%$ (28 students) successfully completing the essay. Next, in Pule I Primary School, Kandat District, out of 40 students, only 10 students (4\%) succeeded in making essays. This fact is shown by the 
IJAMSR 3 (5) www.ijamsr.com CrossRef: https://doi.org/10.31426/ijamsr.2020.3.5.3314

\section{International Journal of Advanced Multidisciplinary Scientific Research (IJAMSR) ISSN:2581-4281}

results of daily tests and midterms that have been carried out. This fact shows that learning to write in elementary schools in Kediri Regency has not been successful. The results of students' writing tests taken as preliminary data can be seen in Table 1 .

Table 1 - Data on Students' Initial Writing Skills.

\begin{tabular}{|c|c|c|c|c|c|}
\hline $\begin{array}{c}\text { Total } \\
\text { student } \\
\mathrm{s}\end{array}$ & $\begin{array}{c}\text { Min } \\
\text { Valu } \\
\mathrm{e}\end{array}$ & $\begin{array}{c}\text { Max } \\
\text { valu } \\
\mathrm{e}\end{array}$ & $\begin{array}{c}\text { The } \\
\text { mea } \\
\mathrm{n}\end{array}$ & $\begin{array}{c}\text { Mod } \\
\mathrm{e}\end{array}$ & $\begin{array}{c}\text { Media } \\
\mathrm{n}\end{array}$ \\
\hline 114 & $\begin{array}{c}21.2 \\
5\end{array}$ & $\begin{array}{c}75.0 \\
0\end{array}$ & $\begin{array}{c}58.3 \\
4\end{array}$ & $\begin{array}{c}59.7 \\
5\end{array}$ & 59.50 \\
\hline
\end{tabular}

Based on Table 1, it can be seen that the average writing ability of students is only 58.34. Even with a minimum value of 21.25. This value indicates that students' writing ability is still low. The finding data were continued with intensive discussion with a number of teachers who taught in class $\mathrm{V}$. The results of the discussion and the information from a number of teachers gave a general picture that the failure was caused by: (1) the teacher failed to create a conducive situation in writing according to the cognitive style of the students, (2) the orientation of learning places more emphasis on results rather than processes, (3) the paradigm of writing as an individual activity is very dominating, (4) learning is still teacher oriented, not empowering students' abilities, and (5) the use of monotonous learning model.

Based on these initial findings, it seems that the failure of writing learning is dominated by the concept of writing learning that is concerned with the results and is an individual activity. The teachers in this context dominate learning while students are not actively involved in completing various writing assignments. The facts found by researchers in class V of Pule I Elementary School in Kandat District, Krecek I Elementary School in Badas District in the implementation of writing essay learning need to be improved. It was revealed that in learning to write essays, the learning model is less varied so that the students experience obstacles in writing. The need of the application that more interesting learning model to improve the student's activity and skills.

Based on these facts, this experimental study was conducted in an effort to find the effect of using cooperative learning model, specifically Group Investigation and Role play on the writing skills of elementary school students. The group investigation learning model is a cooperative learning model that maximally 
IJAMSR 3 (5) www.ijamsr.com CrossRef: https://doi.org/10.31426/ijamsr.2020.3.5.3314

\section{J A M S R}

\section{International Journal of \\ Advanced Multidisciplinary Scientific Research (IJAMSR) ISSN:2581-4281}

involves the students in learning activities ranging from planning the topics to be studied, how to carry out the investigation, to conducting group presentations and evaluations (Fahradina \& Ansari, 2014)

The group investigation model requires the students to learn in groups and be able to coordinate with other group members in problem solving. This learning model, the students are given full power to choose their own topics from learning so they know the picture to be learned and how to carry out investigations (Sangadji, 2016). In applying the group investigation model to learning, good communication skills between the students are needed to expedite the process of the group process so that before investigating the group the teacher is expected to provide communication training to the students. Successful implementation of group investigations is very dependent on (Asyari, Al Muhdhar, \& Susilo, 2016).

The teacher's position in the Group Investigation learning model, it is explained that the teacher acts as a facilitator who directs the processes that occur in groups (helping students formulate plans, implement, managing the groups). Besides the teacher does not play a role as a source of information in learning, but rather is more student-centered (Zulaeha, 2015). The students look for sources themselves that support the material being studied such as the environment around students, study books, newspapers, articles or journals on the internet, and so on. The students can search for learning resources not only from the teacher but the students can search from films, various reading materials, picture books, articles, and others. Thus, the teacher is only a consultant of the group and makes the wise decision (Hartoto, 2016).

The six stages in implementing the group investigation learning model are the grouping stage, the planning stage, the investigation stage, the organizing stage, the presenting stage, and the evaluating stage. In the first stage, the students choose specific sub-topics that have been assigned by the teacher and then they are organized into task-oriented groups. Second, the group plans their investigation. Third stage, the group conducts an investigation as planned in the second stage. The fourth stage, the group plans a presentation. The fifth stage, the group made a presentation. In the eighth stage, the students and the teachers evaluate each group's 
IJAMSR 3 (5) www.ijamsr.com CrossRef: https://doi.org/10.31426/ijamsr.2020.3.5.3314

\section{J A M S R}

\section{International Journal of Advanced Multidisciplinary Scientific Research (IJAMSR) ISSN:2581-4281}

contribution to classwork as a whole. Evaluations can be in the form of individual or group assessments, or both (Masitoh, 2016; Suherman, 2017).

Role play is based on the view that it is possible to create original analogies that are the same as real life problems and through repetition of these events, the students can understand and reflect on the "sample" of life. Therefore, characterization brings out the emotional responses and original behaviours that are characteristic of each student. Role play is believed to encourage students to express their feelings and even let go. This model also assumes that psychological processes involve a person's attitudes, values and beliefs and lead to awareness through spontaneous involvement accompanied by analysis (Andriati, 2015).This model helps each student to find personal meaning in their social world and helps solve personal problems with the help of social groups. In the social dimension, this model makes it easy for individuals to work together in analyzing social conditions, especially problems between people. The role play model also plays an important role in the development of polite and democratic attitudes in dealing with problems (Sari, Saputro, \& Hastuti, 2014).

The essence of role play model is the involvement of the participants and the observers in the context of solving the actual problems and the desire to bring up peaceful resolutions and understand what arises from such involvement. The role play process is useful: (1) exploring the students' feelings, (2) transferring and realizing views about the students' behaviour, values, and perceptions, (3) developing problem solving skills and behaviour, and (4) exploring subject matter with different ways. Based on the four uses it can be concluded that the learning process in the role play model implicitly advocates a real experience that can emerge a number of emotional responses and students' behaviour significantly (Ananda, 2018).

The success of the learning model through role play depends on the quality of the role play (enactment) followed by an analysis of it. In addition, it also depends on students' perceptions about the role played in real life situations (Herlina, 2016; Tuken, 2016). The role play procedure consists of nine steps, namely (1) warming up the atmosphere of the group (warming up), (2) selecting participants, 
IJAMSR 3 (5) www.ijamsr.com CrossRef: https://doi.org/10.31426/ijamsr.2020.3.5.3314

\section{J A M S R}

\section{International Journal of \\ Advanced Multidisciplinary Scientific Research (IJAMSR) ISSN:2581-4281}

(3) setting the setting (set the stage), (4) preparing the researcher / observer, (5) ) enact, (6) discussing and evaluating, (7) re-enacting, (8) second discussion and evaluation, and (9) sharing and generalizing experiences. Each of these steps has a specific goal in developing the ability to collaborate with peers. For this reason, teachers are expected to be able to take advantage of problem situations and want to motivate students to act, and can facilitate students in discussions to give one character to each student.

\section{Research Model}

This research was conducted at the Public Elementary School of the District Education Office in Kediri, with the consideration that the research location was easily accessible from official research assignments. This research was conducted in the even semester of the 2019/2020 school year. The research model used in this study is the experimental model. The population in this study were all students of class V Semester II Public Elementary School in Kediri, East Java, Indonesia with a total of 116,443 students spread across 619 public elementary schools. The sample of this study as a whole numbered 240 grade V students of State Elementary Schools, which were found in 12 elementary schools located in three districts namely (1) Kandat District, (2) Ngadiluwih District, and (3) Badas District. Sampling was carried out with a multi-stage area random sampling technique of 116. 443 students spread over 26 sub-districts in Kediri Regency. The class is divided into 2, namely the experimental class with a total sample of 126 students and a control class with a total sample of 114 students. The experimental class is a class that is treated by providing a group investigation learning model and the control class is a class that is treated by providing a role play learning model. The independent variable of this study is the learning model while the dependent variable is writing skills. Data collection uses tests, questionnaires, and documentation. The data analysis technique used independent sample t-test. This test is carried out to compare two samples which are not in pairs (Christensen, 2020).The research hypothesis is:

$\mathrm{H} 0=$ There is no difference in the average writing skills of students taught using the group investigation model with the role play model. 
IJAMSR 3 (5) www.ijamsr.com CrossRef: https://doi.org/10.31426/ijamsr.2020.3.5.3314

\section{J A M S R}

\section{International Journal of Advanced Multidisciplinary Scientific Research (IJAMSR) ISSN:2581-4281}

$\mathrm{Ha}=$ There is a difference in the average writing skills of students taught using the group investigation model and the role play model.

\section{Research Results \\ Research Data}

Table 2 - Group Statistics

\begin{tabular}{|l|l|c|c|c|c|}
\hline \multicolumn{7}{|c|}{ Group Statistics } \\
\hline \multirow{2}{*}{} & Study model & $\mathrm{N}$ & $\begin{array}{c}\text { The } \\
\text { mean }\end{array}$ & $\begin{array}{c}\text { Std. } \\
\text { Deviation }\end{array}$ & $\begin{array}{c}\text { Std. } \\
\text { Error } \\
\text { Mean }\end{array}$ \\
\hline $\begin{array}{l}\text { Writing } \\
\text { skills }\end{array}$ & $\begin{array}{l}\text { Group } \\
\text { Investigations }\end{array}$ & 126 & 80.4206 & 10.63154 & .94713 \\
\cline { 2 - 6 } & Role Play & 114 & 76.3421 & 10,54013 & .98717 \\
\hline
\end{tabular}

Based on Table 2 on the output of "Group Statistics" it is known that the number of students writing skills data taught using the group investigation model is 126 people with an average value of 80.42 , while for groups with the role play model are 114 people with an average score of 76,34 . Thus in descriptive statistics it can be concluded that there are differences in the average writing skills of students taught using the group investigation model with the role play model.
The spread of the distribution of the value of writing skills of students who follow the learning model of Group Investigation can be seen in the following histogram.

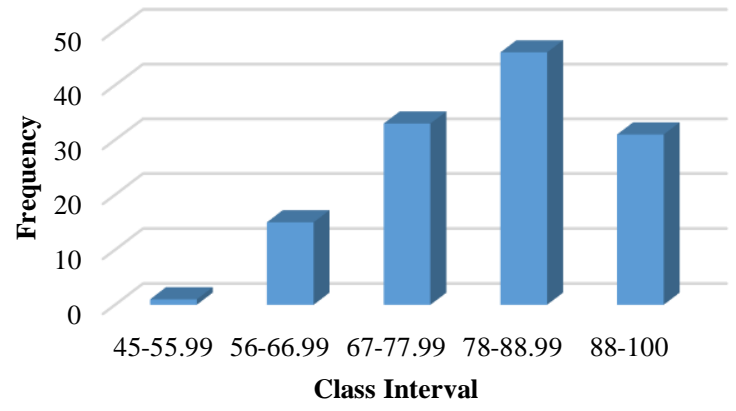

Figure 1 - The Value of Writing Skills Using the Group Investigation Learning Model

Table 3 - Description of Student Writing Skill Values Using the Group Investigation Learning Model

\begin{tabular}{|c|c|c|c|c|c|c|c|}
\hline $\begin{array}{c}\text { Stude } \\
\text { nt } \\
\text { Group }\end{array}$ & $\mathrm{N}$ & $\begin{array}{c}\text { Min } \\
\text { Valu } \\
\mathrm{e}\end{array}$ & $\begin{array}{c}\text { Max } \\
\text { valu } \\
\mathrm{e}\end{array}$ & $\begin{array}{c}\text { The } \\
\text { mea } \\
\mathrm{n}\end{array}$ & Mo & Me & $\mathrm{S}$. \\
\hline IK & $\begin{array}{c}12 \\
6\end{array}$ & $\begin{array}{c}55.0 \\
0\end{array}$ & $\begin{array}{c}98.7 \\
5\end{array}$ & $\begin{array}{c}80.4 \\
2\end{array}$ & $\begin{array}{c}86.2 \\
5\end{array}$ & $\begin{array}{c}82.5 \\
0\end{array}$ & $\begin{array}{c}9.50 \\
06\end{array}$ \\
\hline
\end{tabular}

Based on Table 3, related to writing skills for groups of students who follow the Group Investigation learning model shows that the highest value of writing skills is 98.75 and the lowest value is 55.00 and has a range of grades 55.00-98.75. Descriptive statistical calculations obtained an average value (mean) of 80.42, mode (Mo) of 86.25, median (Me) of 82.50, 
IJAMSR 3 (5) www.ijamsr.com CrossRef: https://doi.org/10.31426/ijamsr.2020.3.5.3314

\section{J A M S R}

\section{International Journal of} Advanced Multidisciplinary Scientific Research (IJAMSR) ISSN:2581-4281

and standard deviation (s) of 9.5006. If referring to Figure 1, the largest value distribution at the interal score of 78 to 88.99 is 46 students. This shows that the writing skills of students through the group investigation model in the category are good.
The spread of the distribution of the value of writing skills of students who follow this Role play learning model can be seen in the following histogram:

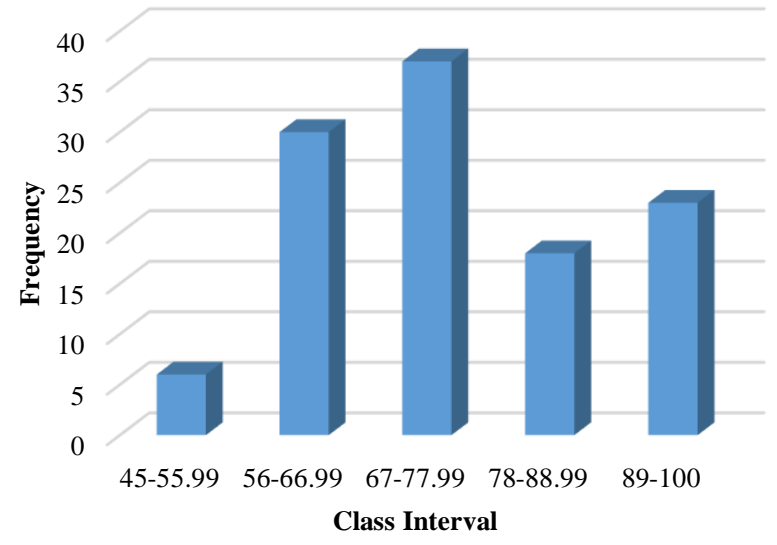

Figure 2 - The Value of Writing Skills Using Role play Learning Model

Table 4 - Description of Student Writing Skill Values Using Role play Learning Model

\begin{tabular}{|c|c|c|c|c|c|c|c|}
\hline Student Group & $\mathrm{N}$ & Min Value & Max value & The mean & Mo & Me & S. \\
\hline BP & 114 & 45.00 & 98.75 & 76.34 & 76.25 & 75.00 & 12,09736 \\
\hline
\end{tabular}

Based on Table 4, related to writing skills for groups of students who follow the Role Play learning model shows that the highest value of writing skills is 98.75 , and the lowest value is 45.00 and has a range of grades 45.00-98.75. Based on descriptive statistical calculations obtained an average value (mean) of 76.34 , mode (Mo) of 76.25, median (Me) of 75.00, and standard deviation (s) of 12.09736. When referring to Figure 2, the largest value distribution is at the interal value of 67 to 77.99. This shows that the writing skills of students through role play model in the category are quite good. 
IJAMSR 3 (5) www.ijamsr.com CrossRef: https://doi.org/10.31426/ijamsr.2020.3.5.3314

International Journal of

Table 5 - Independent Samples Test

\begin{tabular}{|c|c|c|c|c|c|c|c|c|c|c|}
\hline \multicolumn{11}{|c|}{ Independent Samples Test } \\
\hline & & \multicolumn{2}{|c|}{$\begin{array}{l}\text { Levene's Test for } \\
\text { Equality of } \\
\text { Variances }\end{array}$} & \multicolumn{7}{|c|}{ t-test for Equality of Means } \\
\hline & & \multirow[b]{2}{*}{$\mathrm{F}$} & \multirow[b]{2}{*}{ Sig. } & \multirow[b]{2}{*}{$\mathrm{t}$} & \multirow[b]{2}{*}{$\mathrm{df}$} & \multirow{2}{*}{$\begin{array}{l}\text { Sig. (2- } \\
\text { tailed) }\end{array}$} & \multirow{2}{*}{$\begin{array}{c}\text { Mean } \\
\text { Difference }\end{array}$} & \multirow{2}{*}{$\begin{array}{l}\text { Std. Error } \\
\text { Difference }\end{array}$} & \multicolumn{2}{|c|}{$\begin{array}{l}95 \% \text { Confidence } \\
\text { Interval of the } \\
\text { Difference }\end{array}$} \\
\hline & & & & & & & & & Lower & Upper \\
\hline \multirow[t]{2}{*}{$\begin{array}{l}\text { Writing } \\
\text { skills }\end{array}$} & \begin{tabular}{|l} 
Equal \\
variances \\
assumed
\end{tabular} & .019 & .890 & 2,980 & 238 & .003 & 4.07853 & 1,36865 & 1.38232 & 6.77474 \\
\hline & $\begin{array}{l}\text { Equal } \\
\text { variances not } \\
\text { assumed }\end{array}$ & & & 2,981 & 236,006 & .003 & 4.07853 & 1.36805 & 1.38337 & 6.77369 \\
\hline
\end{tabular}

Furthermore, based on Table 5, the Sig. Lavene's Test for Equality of Variance of $0.890>0.05$. Then it can be interpreted that the data variance of the two groups is homogeneous (V. Wiratna Sujarweni: 2014). If viewed from the Independent Samples Test output on "Equal variances assumed" the Sig value is known. (2-tailed) of $0.003<0.05$. Then it can be concluded that $\mathrm{HO}$ is rejected and $\mathrm{Ha}$ is accepted. Thus it can be concluded that there are differences in the average writing skills of students taught using the group investigation model with the role play model. On the value of "Mean Difference" known value of 4.07 which shows the average difference between the writing skills of students who are taught using the group investigation model with the role play model.

The results of the analysis test show that Indonesian writing skills among groups of the students who follow the Group Investigation learning model are better than Indonesian writing skills groups of the students who follow the Role Play learning model. Research findings prove that groups of students who learn with the Group Investigation learning model are more effective (Untoro, 2016; Wulansari \& Zulaeha, 2018). 
IJAMSR 3 (5) www.ijamsr.com CrossRef: https://doi.org/10.31426/ijamsr.2020.3.5.3314

\section{J A M S R}

\section{International Journal of Advanced Multidisciplinary Scientific Research (IJAMSR) ISSN:2581-4281}

This significant difference is due to the group of students who participate in learning with the Group Investigation model being able to express and develop their ideas in a wellstructured way (Rosadi, 2017). Whereas the group of students who follow the Role play model cannot effectively develop their ideas (Husna, Utami, \& Wahyuni, 2016). The Group Investigation Model provides opportunities for students to express their ideas in stages that are easy for the students to follow in their elementary school age. This learning model provides great opportunities for the students and the teachers to plan the form and content of writing to the full. What is more important than the Group Investigation learning model is that it provides a large opportunity for the students to conduct investigations in a considerable amount of time. The stages of the presentation of the report in this model also contribute very well to the students to mutually respond, correct, and evaluate for the perfection of the writing so that a learning process occurs with better results. These processes and activities have an effect on student understanding related to writing activities. The intended effect is that students' understanding becomes stronger and better and deeper can even produce productive understanding (Hakim \& Subyantoro, 2018).
While role play tends to be quite heavy when applied in learning to write, although from the aspect of the process is very good and has many advantages, especially if directed to increase appreciation, mastery of the material, and the development of imagination. The teacher must be able to choose interesting topics that can be written with this model (Khanifah, 2018; Sapdiani, 2019). It is said to be heavy because of the cognitive development and knowledge of elementary school students to carry out playful appreciation is indeed a challenge for teachers in their implementation. Role Play is a cooperative learning model that emphasizes student activities in doing case roles on the subject matter being discussed with the aim that the students have increased understanding and appreciation. 
IJAMSR 3 (5) www.ijamsr.com CrossRef: https://doi.org/10.31426/ijamsr.2020.3.5.3314

\section{International Journal of \\ I J A M S R \\ Advanced Multidisciplinary Scientific Research (IJAMSR) ISSN:2581-4281}

Table 6 - Differences in the Model of Group Investigation and Role Play Learning

\begin{tabular}{|c|c|c|}
\hline $\begin{array}{l}\text { Element } \\
\text { Model }\end{array}$ & $\begin{array}{c}\text { Group Investigation } \\
\text { (GI) }\end{array}$ & $\begin{array}{l}\text { Role Play } \\
\text { (RP) }\end{array}$ \\
\hline $\begin{array}{l}\text { Principles of } \\
\text { Management / } \\
\text { Reaction }\end{array}$ & $\begin{array}{l}\text { Teachers play more roles as the friendly } \\
\text { conselors, consultants, and critics. In this } \\
\text { framework the teacher guides and manages } \\
\text { the class through three stages, namely the } \\
\text { stage of problem solving, classroom } \\
\text { management, and individual meanings. More } \\
\text { concerned with peer tutors, so members of the } \\
\text { group who first understand the material must } \\
\text { explain to the members who have not } \\
\text { mastered }\end{array}$ & $\begin{array}{l}\text { The teacher acts more as a motivator and } \\
\text { facilitator. In this context the teacher helps } \\
\text { students explore various aspects of the } \\
\text { problem situation and compare several } \\
\text { alternative solutions to the problem. The } \\
\text { teacher accepts all students' responses without } \\
\text { judgment and increases students' awareness } \\
\text { about the importance of the material. }\end{array}$ \\
\hline Syntactic & $\begin{array}{l}\text { (1) Identify topics and organize the students } \\
\text { into groups heterogeneously with } \\
\text { members of } 4-5 \text { students (grouping). } \\
\text { (2) Plan tasks to be learned (planning). } \\
\text { (3) Conduct an investigation (investigation.) } \\
\text { (4) Prepare a final report (organizing). } \\
\text { (5) Presenting the final report (presenting). } \\
\text { (6) Evaluating. }\end{array}$ & $\begin{array}{l}\text { (1) Warming up the group atmosphere } \\
\text { (warming up). } \\
\text { (2) Select participants. } \\
\text { (3) Set the settings (set the stage) } \\
\text { (4) Prepare. researcher / observer } \\
\text { (5) Characterization (enact). } \\
\text { (6) Discuss and evaluate (discussion and } \\
\text { evaluation). } \\
\text { (7) Play back. } \\
\text { (8) Second discussion and evaluation. } \\
\text { (9) Share and generalize experiences. }\end{array}$ \\
\hline $\begin{array}{l}\text { Supporting } \\
\text { System }\end{array}$ & $\begin{array}{l}\text { Supporting facilities needed to implement this } \\
\text { model are all things that touch the needs of the } \\
\text { students to be able to explore the various } \\
\text { information that is appropriate and needed to } \\
\text { do the group problem solving process. Typically } \\
\text { LKS is prepared in the form of activities and } \\
\text { questions that require analytical answers that } \\
\text { require investigation activities. }\end{array}$ & $\begin{array}{l}\text { Supporting facilities in the form of } 1 \text { interesting } \\
\text { theme that must be discussed and played by } \\
\text { each group. It is recommended that each group } \\
\text { discuss and portray different themes so that } \\
\text { learning is more memorable, interesting, and } \\
\text { varied. }\end{array}$ \\
\hline $\begin{array}{l}\text { Instructional and } \\
\text { Accompaniment } \\
\text { Impacts }\end{array}$ & $\begin{array}{l}\text { The GI model is very interesting, useful, and } \\
\text { comprehensive, because it combines research } \\
\text { activities, social integration, and constructivist } \\
\text { learning concepts. Specifically the instructional } \\
\text { impact is (1) the process and group } \\
\text { management can be effective, (2) educating } \\
\text { students to have high discipline in collaborative } \\
\text { learning, and (3) students are actively directed } \\
\text { to learn through the process of constructivist } \\
\text { knowledge formation. }\end{array}$ & $\begin{array}{l}\text { The RP model is specifically regulated to } \\
\text { educate the students in (1) analysis of the } \\
\text { values and behaviour of each individual, (2) } \\
\text { developing strategies in solving interpersonal } \\
\text { and personal problems, (3) developing empathy } \\
\text { for others. The accompanying impact is comfort } \\
\text { in issuing opinions, negotiating skills, and } \\
\text { integration in problem solving }\end{array}$ \\
\hline
\end{tabular}


IJAMSR 3 (5) www.ijamsr.com CrossRef: https://doi.org/10.31426/ijamsr.2020.3.5.3314

\section{J A M S R}

International Journal of Advanced Multidisciplinary Scientific Research (IJAMSR) ISSN:2581-4281

In determining students' writing skills, a short experience writing test is conducted with a predetermined theme of 3 paragraphs. The assessed aspects are aspects: a. content (weight $30 \%$ ) includes the relevance of the content based on the topic, $b$. the organization of the essay contents (weighting 20\%) includes wholeness. and paragraph linking, organized ideas in logical order, c. cohesive and coherence (20\% weight) includes mastering word formations and composing effective sentences, d. word choice (weighting 25\%) includes the accuracy of the choice of words and expressions and, e. use of spelling and punctuation (5\% weight) includes the use of letters and punctuation.

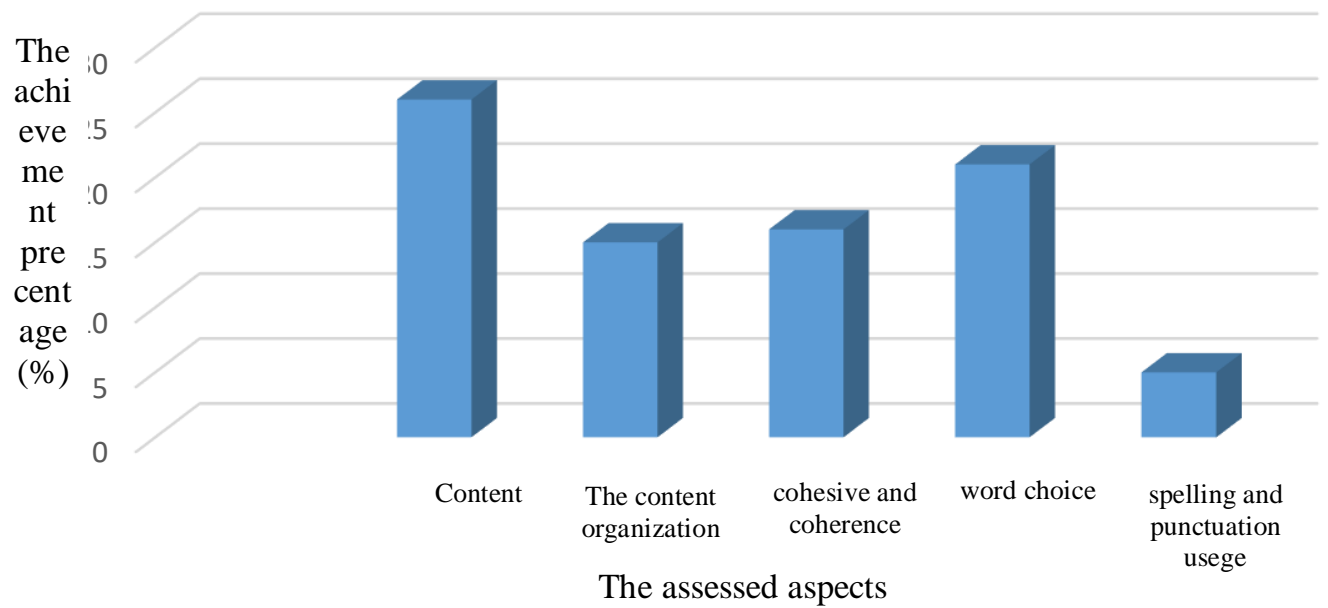

Figure 3 - Percentage of Student Writing Ability Achievement Based on Group Investigation Learning Model

Based on Figure 3, the percentage of content aspect is $26 \%$, content organization is $15 \%$, cohesive and coherence is $16 \%$, word choice is $21 \%$, and spelling and punctuation usege is $5 \%$. The total percentage of achievements was $83 \%$. 


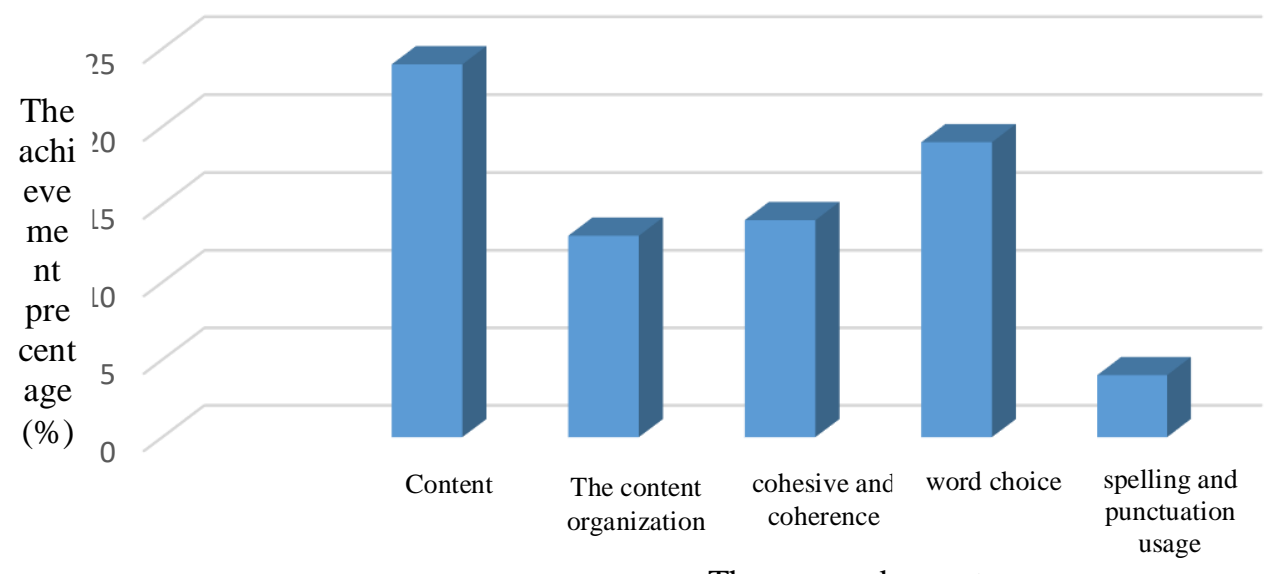

The assessed aspects

Figure 4 - Percentage Of Student Writing Ability Achievement Based On Role Play Learning Model

Based on Figure 4, the percentage of the content aspect is $24 \%$, the content organization is $13 \%$, cohesive and coherence is $14 \%$, word choice is $19 \%$, and spelling and punctuation usege is $4 \%$. The total percentage of achievements was $74 \%$. The following are examples of narrative paragraphs that are not cohesive and incoherent.

\section{Examples Of Student Essays:}

(1) Day starts at noon, our family prepares to go to Kediri City. (2) We estimated that at the latest we would arrive in Tofu City for about two hours. (3) After two hours we departed from Surabaya. (4) The big gate has welcomed us without speaking.

The paragraph is negative because it tells the character's actions in chronological order. Even though it uses a cohesive citation marker and repetition, the paragraph is not cohesive because there are unacceptable sentences and unclear sentence meaning (Mohamed, 2014), namely in sentences (2) and (3). In both sentences there is the use of two-hour phrases, the two-hour phrase shows the time period, the time period used to indicate the length of time required to carry out a process / activity. To express the time of departure or arrival to a place, words / phrases that indicate time, for 
IJAMSR 3 (5) www.ijamsr.com CrossRef: https://doi.org/10.31426/ijamsr.2020.3.5.3314

\section{International Journal of Advanced Multidisciplinary Scientific Research (IJAMSR) ISSN:2581-4281}

example, at 6:00 a.m., in the morning, in the afternoon, and so on indicate time, not time period. So the use of two-hour phrases in sentences (2) and (3) is incorrect.

In terms of the relationship between meanings, the paragraph is also incoherent because of the unclear chronological ties in the story, and the obscurity of objects referred to by large archway phrases. Along the Surabaya-Kediri journey, there are many large gates. Which big gate is meant by the writer? This sentence was not revealed by the sentence so that it disturbs the understanding of the discourse. For these reasons, the paragraph above is categorized as a narrative paragraph that is not cohesive and incoherent.

\section{Conclusion}

The conclusions obtained from the study indicate that the learning model influences students' writing skills. Statistical tests also showed that there were differences in the average writing skills of students taught using the group investigation model with the role play model as indicated by the Sig. (2-tailed) of $0.003<0.05$ (H0 rejected). The difference lies in the group of students who follow the group Investigation learning model shows that the highest value of writing skills is 98.75 and the lowest value is 55.00, and the average value is 80.42. Whereas the group of students who followed the Role Play model showed that the highest value of writing skills was 98.75 , and the lowest value was 45.00 , and the average value was 76.34 . The results show that the group investigation model is better and more effective in the learning process than the role play model. Writing skills assessment aspects in this study were carried out through tests with the assessment aspects including: (1) content (weight 30\%), (2) organization of essay content (weight 20\%), (3) cohesive and coherence paragraph (weight 20\%), (4) choice of words (25\% weight), (5) use of spelling and punctuation (5\% weight).

\section{References}

[1] Ananda, R. (2018). Peningkatan Pembelajaran PKn dengan Penerapan Metode Role-Playing Siswa Kelas II SDN 003 Bangkinang Kota. Jurnal Basicedu, 2(1), 33-42.

[2] Andriati, N. (2015). Pengembangan Model Bimbingan Klasikal Dengan Teknik Role Playing Untuk Meningkatkan Kepercayaan Diri. Jurnal Bimbingan Konseling, 4(1).

[3] Astuti, Y. W., \& Mustadi, A. (2014). Pengaruh penggunaan media film animasi terhadap keterampilan menulis karangan narasi siswa kelas V SD. Jurnal Prima Edukasia, 2(2), 250-262.

[4] Asyari, M., Al Muhdhar, M. H. I., \& Susilo, H. (2016). Improving critical thinking skills through the integration of problem based learning and group investigation. International Journal for Lesson and Learning Studies. 
IJAMSR 3 (5) www.ijamsr.com CrossRef: https://doi.org/10.31426/ijamsr.2020.3.5.3314

\section{International Journal of}

[5] Christensen, R. (2020). One-way ANOVA. In Plane Answers to Complex Questions (pp. 107121). Springer.

[6] Fahradina, N., \& Ansari, B. I. (2014). Peningkatan Kemampuan Komunikasi Matematis dan Kemandirian Belajar Siswa SMP dengan Menggunakan Model Investigasi Kelompok. Jurnal Didaktik Matematika, 1(2).

[7] Hakim, L., \& Subyantoro, S. (2018). Learning Writing Explanatory Text Using Group Investigation Based on Learning Style. Seloka: Jurnal Pendidikan Bahasa Dan Sastra Indonesia, 7(3), 259-266.

[8] Hartoto, T. (2016). Model Pembelajaran Kooperatif Tipe Group Investigation (GI) Meningkatkan Aktivitas dan Hasil Belajar Sejarah. HISTORIA: Jurnal Program Studi Pendidikan Sejarah, 4(2), 131-142.

[9] Herlina, U. (2016). Teknik Role Playing dalam Konseling Kelompok. Sosial Horizon: Jurnal Pendidikan Sosial, 2(1), 94-107.

[10] Husna, N., Utami, C., \& Wahyuni, R. (2016). Pengaruh Model Role Playing Terhadap Kemampuan Komunikasi Matematis Siswa Pada Materi Fungsi Komposisi Kelas XI Sma Negeri 6 Singkawang. JPMI (Jurnal Pendidikan Matematika Indonesia), 1(2), 81-86.

[11] Khanifah, L. N. (2018). Pengembangan Perangkat Pembelajaran dengan Pemanfaatan Cerita Rakyat Melalui Model Project Based Learning (PJBL) Berbasis Role Playing dalam Meningkatkan Keterampilan Sosial Peserta Didik. MIDA: Jurnal Pendidikan Dasar Islam, l(1).

[12] Lin, M. H., Li, J.-J., Hung, P. Y., \& Huang, H.W. (2014). Blogging a journal: Changing students' writing skills and perceptions. ELT Journal, 68(4), 422-431.

[13] Malladewi, M. A. (2013). Peningkatan Keterampilan Menulis Narasi Ekspositoris melalui Jurnal Pribadi Siswa Kelas IV di SD Negeri Balasklumprik I/434 Surabaya. Jurnal Penelitian Pendidikan Guru Sekolah Dasar, 1(2), $1-11$.

[14] Masitoh, S. (2016). Peningkatan Aktivitas Belajar dengan Pembelajaran Investigasi Kelompok dalam Kuliah Metode Penelitian PLB II. Jurnal Ilmu Pendidikan, 13(2).

[15] Mohamed, T. H. (2014). Cohesion and Coherence Interrelation: An Approach to Literary Translation-Mahfouz's Trilogy. International Journal of Linguistics Al Obour High Institutes.

[16] Rosadi, L. D. (2017). Keefektifan Pembelajaran Mengkonstruksi Teks Negosiasi Menggunakan Model Investigasi Kelompok dan Model Problem Based Learning Berbantuan Media Video Bertema Kewirausahaan Pada Peserta Didik Kelas X SMK. Universitas Negeri Semarang.
[17] Sangadji, S. (2016). Implementation of cooperative learning with group investigation model to improve learning Achievement of vocational school students in Indonesia. International Journal of Learning \& Development, 6(1), 91-103

[18] Sapdiani, R. (2019). Implementasi Model Pembelajaran Role Playing dalam Meningkatkan Kemampuan Menulis Teks Prosedur pada Siswa Kelas VII Sekolah Menengah Pertama (SMP). Jurnal Akrab Juara, 4(1), 29-40.

[19] Sari, K. W., Saputro, S., \& Hastuti, B. (2014). Pengembangan game edukasi kimia berbasis role playing game (RPG) pada materi struktur atom sebagai media pembelajaran mandiri untuk siswa kelas X SMA di kabupaten Purworejo. Jurnal Pendidikan Kimia, 3(2), 96-104.

[20] Suherman, M. (2017). PENERAPAN MODEL GROUP INVESTIGATION UNTUK MENINGKATKAN KEMAMPUAN DAN HASIL BELAJAR SISWA PADA MATA PELAJARAN PENJASORKES DI KELAS $\mathrm{X}$ IPS 4 SMA NEGERI 3 CIREBON. Syntax Literate; Jurnal Ilmiah Indonesia, 2(3), 84-98.

[21] Tuken, R. (2016). Peningkatan Hasil Belajar Siswa pada Mata Pelajaran Pkn Melalui Pembelajaran Kooperatif tipe Role Playing di Kelas VI SDN IV Kota Parepare. Publikasi Pendidikan: Jurnal Pemikiran, Penelitian Dan Pengabdian Masyarakat Bidang Pendidikan, 6(2).

[22] Untoro, B. (2016). The Effect of Group Investigation and Learning Style on Students' Writing of Analytical Exposition. IJEE (Indonesian Journal of English Education), 3(1), 29-45.

[23] Wulansari, D. E., \& Zulaeha, I. (2018). Keefektifan Pembelajaran Menyusun Teks Eksplanasi dengan Model Investigasi Kelompok dan Problem Based Learning pada Peserta Didik Kelas VII SMP. Jurnal Pendidikan Bahasa Dan Sastra Indonesia, 7(2), 22-28

[24] Yarmi, G. (2014). Meningkatkan Kemampuan Menulis Kreatif Siswa Melalui Pendekatan Whole Language dengan Teknik Menulis Jurnal. Perspektif Ilmu Pendidikan, 28(1), 8-16.

[25] Zulaeha, I. (2015). Model Investigasi Kelompok dengan Teknik Adu Argumen sebagai Upaya Peningkatan Kompetensi Pedagogik Calon Guru Bahasa Indonesia. Jurnal Penelitian Pendidikan, 32(1). 